\title{
Zirconium enolatoimine complexes in olefin polymerization $\uparrow$
}

\author{
Sze-Man Yu, Ulrich Tritschler, Inigo Göttker-Schnetmann and Stefan Mecking*
}

\begin{abstract}
Zirconium complexes with enolatoimine ligands bearing an electron-withdrawing trifluoromethyl group on the alkoxy moiety $\left[\kappa^{2}-N, O-\left\{2,6-\mathrm{R}_{2} \mathrm{~N}=\mathrm{C}\left(\mathrm{CH}_{3}\right) \mathrm{C}(\mathrm{H})=\mathrm{C}(\mathrm{O}) \mathrm{CF}_{3}\right]_{2} \mathrm{ZrCl}_{2}(2 \mathrm{a}, \mathrm{R}=\mathrm{H} ; \mathbf{2 b}, \mathrm{R}=\mathrm{F} ; \mathbf{2 c}\right.$, $\mathrm{R}=\mathrm{CH}_{3} ; \mathbf{2 d}, \mathrm{R}={ }^{\mathrm{i}} \mathrm{Pr}$ ) were prepared. The isopropyl substituents hinder rotation in solution for $\mathbf{2 d}$, and result in a trans-arrangement of the $\mathrm{N}$-donors in the solid state. Catalyst activities are similar for $2 \mathrm{a} / \mathrm{MAO}$ and $\mathbf{2 b} / \mathrm{MAO}$ in ethylene polymerization $\left(1.8 \times 10^{5} \mathrm{TO}^{-1}\right.$ for $2 \mathrm{a}$ and $3.3 \times 10^{5} \mathrm{TO}^{-1}$ for $\mathbf{2 b}$ at $25^{\circ} \mathrm{C}$ under 1 bar monomer pressure), increasingly bulky alkyl substituents result in strongly decreased polymerization activities $\left(7.1 \times 10^{2} \mathrm{TO} \mathrm{h}^{-1}\right.$ for $2 \mathrm{c}$ and $5.7 \times 10^{2} \mathrm{TO} \mathrm{h}^{-1}$ for $2 \mathrm{~d}$ at $\left.25^{\circ} \mathrm{C}\right)$. This goes along with an increase in polymer molecular weight $\left(M_{\mathrm{w}}=8.1 \times 10^{3}, M_{\mathrm{w}} / M_{\mathrm{n}}=2.9\right.$ for $2 \mathrm{a}, M_{\mathrm{w}}=$ $3.8 \times 10^{5}, M_{\mathrm{w}} / M_{\mathrm{n}}=2.0$ for $2 \mathrm{~b}, M_{\mathrm{w}}=1.0 \times 10^{6}, M_{\mathrm{w}} / M_{\mathrm{n}}=2.8$ for $2 \mathrm{c}$ ), apparently bulky substituents retard chain transfer even more strongly than activation of the precursors and/or chain growth. $2 \mathrm{~b} / \mathrm{MAO}$ affords atactic polypropylene $\left(M_{\mathrm{w}}=1.4 \times 10^{4} \mathrm{~g} \mathrm{~mol}^{-1}, M_{\mathrm{w}} / M_{\mathrm{n}}=2.1\right)$ with a small portion of regioirregular structures. The reaction of $\left[\mathrm{Zr}\left(\mathrm{CH}_{2} \mathrm{Ph}\right)_{4}\right]$ with the ketoenamine $2,6-\mathrm{F}_{2} \mathrm{C}_{6} \mathrm{H}_{3} \mathrm{~N}(\mathrm{H})$ $\mathrm{CMe}=\mathrm{CHC}(\mathrm{O}) \mathrm{CF}_{3}(\mathbf{1 b})$ yielded the dibenzyl complex $\left[\left(o-\mathrm{F}_{2} \mathrm{C}_{6} \mathrm{H}_{3} \mathrm{~N}=\mathrm{CMeCH}=\mathrm{C}\left(\mathrm{CF}_{3}\right) \mathrm{O}\right)_{2} \mathrm{Zr}-\right.$ $\left.\left(\mathrm{CH}_{2} \mathrm{Ph}\right)_{2}\right](3 \mathrm{~b})$ which was investigated as a catalyst precursor for ethylene homopolymerization in combination with different activators.
\end{abstract}

\section{Introduction}

Single-site catalysts, based on well-defined metal complexes as catalyst precursors, have contributed tremendously to a fundamental understanding of olefin polymerization, and provide access to polymers with novel controlled microstructures. ${ }^{1}$ They have also promoted the further development and improvement of heterogeneous Ziegler catalysts. In addition to metallocenes, non-metallocene complexes of early and late transition metals with bidentate chelate ligands have found strong interest more recently. ${ }^{2,3}$ Significant advances, specifically concerning control of molecular weight and polymer architecture by living polymerization, branching, as well the generation of unique morphologies in the form of nanoscale crystals have been made recently with both group 4 and group 8 metal complexes of salicyliminato ligands. ${ }^{4-9}$ This has prompted studies of structurally related enolatoimine complexes, ${ }^{10}$ which, in some cases, indeed possess advantageous catalytic properties, such as a high stability during polymerization." We have previously communicated that a $\mathrm{Ti}$ complex of an enolatoimine $\left[\left(\kappa^{2}-N, O-o-\mathrm{R}_{2} \mathrm{C}_{6} \mathrm{H}_{3} \mathrm{~N}=\mathrm{CMeCH}=\mathrm{C}\left(\mathrm{CF}_{3}\right) \mathrm{O}\right)_{2} \mathrm{TiCl}_{2}\right]$ with an electron-withdrawing $\mathrm{CF}_{3}$-substituted alkoxy moiety and 2,6F-substitution of the $\mathrm{N}$-aryl moiety $(\mathrm{R}=\mathrm{F})$ polymerizes ethylene in an unprecedented living fashion affording polymer with a high

Chair of Chemical Materials Science; Dept. of Chemistry; University of Konstanz, 78464, Konstanz, Germany. E-mail: stefan.mecking@ uni-konstanz.de; Fax: $+49753188-5152 ;$ Tel: $+49753188-5151$

$\uparrow$ Electronic supplementary information (ESI) available: Figures showing mass flow data and GPC profiles for polyethylenes, figures depicting ${ }^{1} \mathrm{H}$ and ${ }^{13} \mathrm{C}$ NMR spectra of polypropylene and table collecting details of the crystal structure determination of $\mathbf{1 d}, \mathbf{2 a - b}, \mathbf{d}$. CCDC reference numbers 743815-743818. For ESI and crystallographic data in CIF or other electronic format see DOI: $10.1039 / \mathrm{b} 916289 \mathrm{e}$ molecular weight $\left(M_{\mathrm{n}}>10^{5} \mathrm{~g} \mathrm{~mol}^{-1}\right)$ and an extremely narrow distribution $\left(M_{\mathrm{w}} / M_{\mathrm{n}}=1.01\right)$ at the same time; the living character is also retained at an elevated temperature of $75{ }^{\circ} \mathrm{C}\left(M_{\mathrm{n}}=\right.$ $2.6 \times 10^{5} \mathrm{~g} \mathrm{~mol}^{-1}, M_{\mathrm{w}} / M_{\mathrm{n}}=1.15$ after $15 \mathrm{~min}$ ) and over $1 \mathrm{~h}$ of polymerization time $\left(M_{\mathrm{n}}=9.9 \times 10^{5} \mathrm{~g} \mathrm{~mol}^{-1}, M_{\mathrm{w}} / M_{\mathrm{n}}=1.17\right.$ at $25^{\circ} \mathrm{C}$ ). Block copolymerization with propylene affords high molecular weight copolymer with a soft atactic polypropylene block. By comparison to the 2,6-F-substituted catalyst precursor, the methyl- and non-substituted $(\mathrm{R}=\mathrm{Me}, \mathrm{H})$ analogues afforded PE with a comparatively much broader polydispersity $\left(M_{\mathrm{w}} / M_{\mathrm{n}}\right.$ - 1.4-2.6). ${ }^{12}$ Other than the $o-F$ substituted complex, these analogues appear to be incompletely activated for polymerization with MAO cocatalyst. This remarkable polymerization behaviour prompted us to study the analogous zirconium systems.

\section{Results and discussion}

\section{Synthesis and characterization of ketoenamine ligands}

The novel bulky substituted ketoenamine 1d was prepared similar to the previously reported 1 a-c. ${ }^{12}$ Condensation reaction of 1,1,1-trifluoro-2,4-pentanedione with the corresponding aniline in dry toluene in the presence of a catalytic amount of $p$ toluenesulfonic acid afforded 4-(2,6-diisopropylphenyl-amino)1,1,1-trifluoro-pent-3-en-2-one (1d) in moderate yield. The crude product was purified by column chromatography. The molecular structure of $1 \mathbf{d}$ was determined by single crystal X-ray diffraction (Fig. 1). NMR data as well as the X-ray structure reveal that $1 d$ exists as the ketoenamine tautomer exclusively in solution as well as in the solid state. The bond distances are in the range of typical $\mathrm{N}-\mathrm{C}$ single bonds (C4-N1: 1.3828(2) $\AA$ ) and $\mathrm{C}=\mathrm{O}$ double bonds (C2-O1: 1.250(2) $\AA$ ). 


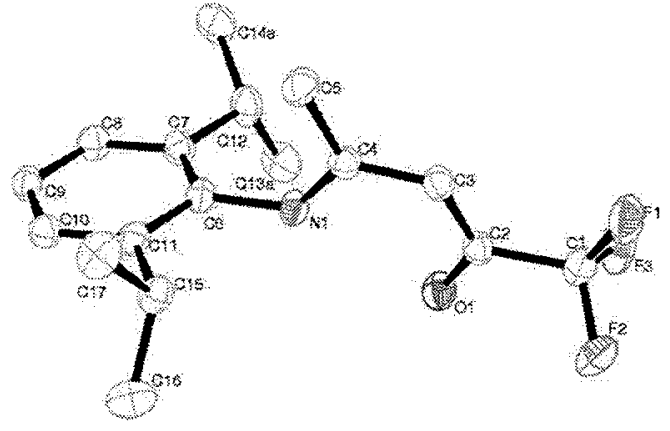

Fig. 1 ORTEP plot of ligand 1d with $50 \%$ probability ellipsoids. Hydrogen atoms and the split position of the disordered ipropyl group C12-C13-C14 are omitted for clarity. Selected bond distances: C4-N1 $1.3828(2) \AA, C 2-011.250(2) \AA$.

\section{Synthesis and characterization of dichloro-complexes}

The addition of a toluenic solution of ketoenamine 1a-d to a solution of $\left[\mathrm{Zr}\left(\mathrm{CH}_{2} \mathrm{Ph}\right)_{2} \mathrm{Cl}_{2}\right]$ at $-30{ }^{\circ} \mathrm{C}$ resulted in expulsion of toluene and formation of the dichloro compounds in virtually quantitative yield (Scheme 1).
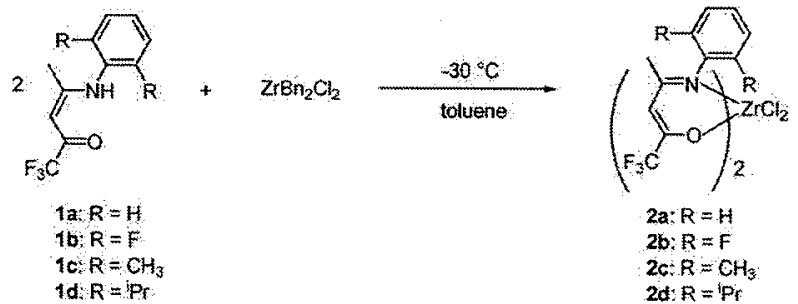

Scheme 1 Synthesis of complexes $\mathbf{2 a - d}$.

Recrystallization of $\mathbf{2 a}, \mathbf{b}$, and $\mathbf{2 d}$ from methylene chloride:pentane at $-30{ }^{\circ} \mathrm{C}$ yielded single crystals suitable for $\mathrm{X}$-Ray diffraction analyses. Complexes $\mathbf{2 a}, \mathbf{b}$, and $\mathbf{2 d}$ exhibit a distorted octahedral geometry with $C_{2}$-symmetry in the solid state (Fig. 2, 3 , and 4 ). In $\mathbf{2} \mathbf{a}, \mathbf{b}$ the two oxygen atoms are oriented trans to one another $\left(\mathrm{O}-\mathrm{Zr}-\mathrm{O}\right.$ angle: $167^{\circ}$ for $2 \mathrm{a}, 163^{\circ}$ for $\left.2 \mathrm{~b}\right)$, while the

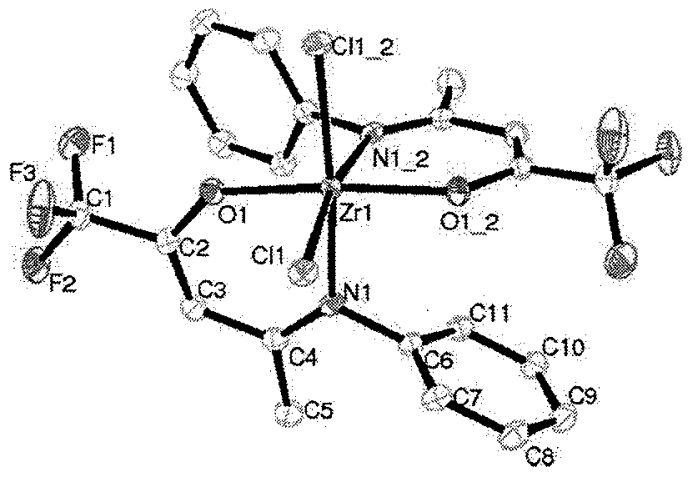

Fig. 2 ORTEP plot of the molecular structure of 2a. Ellipsoids are shown with $50 \%$ probability. $\mathrm{H}$-atoms are not shown for clarity.

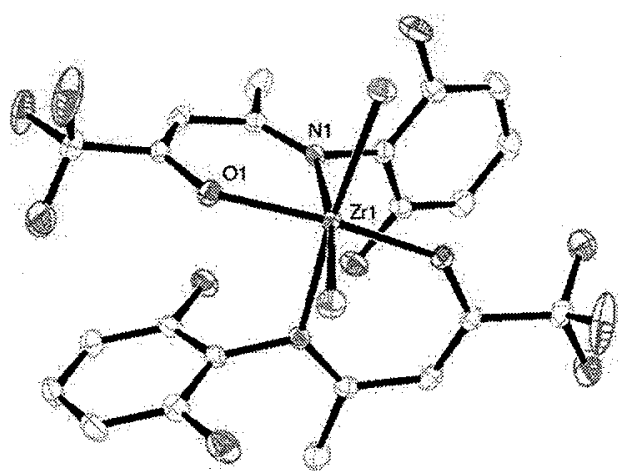

Fig. 3 ORTEP plot of the molecular structure of $\mathbf{2 b}$. Ellipsoids are shown with $50 \%$ probability. H-atoms are not shown for clarity.

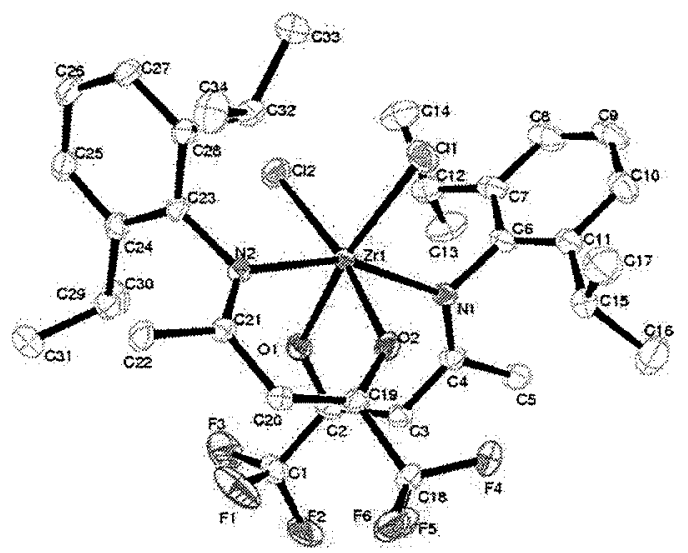

Fig. 4 ORTEP plot of the molecular structure of $2 \mathbf{d}$. Ellipsoids are shown with $50 \%$ probability. $\mathrm{H}$-atoms are not shown for clarity.

two nitrogen atoms $\left(\mathrm{N}-\mathrm{Zr}-\mathrm{N} 81^{\circ}\right.$ for $2 \mathrm{a}, 86^{\circ}$ for $\left.2 \mathrm{~b}\right)$ and the two chlorine atoms $\left(\mathrm{Cl}-\mathrm{Zr}-\mathrm{Cl}\right.$ angle, $99^{\circ}$ for $2 \mathrm{a}, 96^{\circ}$ for $\left.2 \mathrm{~b}\right)$ are arranged in a cis fashion.

In contrast, complex $2 d$ (Fig. 4) adopts a distorted octahedral structure with a trans $\mathrm{N}\left(\mathrm{N}-\mathrm{Zr}-\mathrm{N}: 159.14^{\circ}\right)$, cis $\mathrm{O}(\mathrm{O}-\mathrm{Zr}-\mathrm{O}$ : $\left.84.94^{\circ}\right)$, and cis $\mathrm{Cl}\left(\mathrm{Cl}-\mathrm{Zr}-\mathrm{Cl}: 93.70^{\circ}\right)$ arrangement, which is likely a consequence of the steric crowding of the isopropyl groups. Selected bond distances and angles are given in Table 1.

In addition to the $\mathrm{X}$-Ray diffraction analyses compounds $\mathbf{2 a -}$ d were characterized by ${ }^{1} \mathrm{H},{ }^{13} \mathrm{C}$, and ${ }^{19} \mathrm{~F}$ NMR spectroscopy as well as elemental analysis. ${ }^{1} \mathrm{H}$ - and ${ }^{13} \mathrm{C}$ NMR resonances were fully assigned by ${ }^{1} \mathrm{H},{ }^{1} \mathrm{H}$ gCOSY, heteronuclear ${ }^{1} \mathrm{H},{ }^{13} \mathrm{C} 2 \mathrm{D}$ NMR and ${ }^{1} \mathrm{H},{ }^{13} \mathrm{C}$ 2D long-range-coupling NMR spectroscopy ( $c f$. experimental section for complete NMR data).

Table 1 Selected bond lengths (Â) and angles (deg) for $2 d$

\begin{tabular}{llll}
\hline & 2d & & 2d \\
\hline $\mathrm{Zr}-\mathrm{O}(1)$ & $2.0481(16)$ & $\mathrm{Cl}(1)-\mathrm{Zr}-\mathrm{Cl}(2)$ & $93.70(3)$ \\
$\mathrm{Zr}-\mathrm{O}(2)$ & $2.0560(16)$ & $\mathrm{N}(1)-\mathrm{Zr}-\mathrm{N}(2)$ & $159.14(6)$ \\
$\mathrm{Zr}-\mathrm{N}(1)$ & $2.3361(18)$ & $\mathrm{O}(1)-\mathrm{Zr}-\mathrm{O}(2)$ & $84.94(7)$ \\
$\mathrm{Zr}-\mathrm{N}(2)$ & $2.3293(18)$ & $\mathrm{N}(1)-\mathrm{Zr}-\mathrm{O}(1)$ & $79.05(6)$ \\
$\mathrm{Zr}-\mathrm{Cl}(1)$ & $2.3948(8)$ & $\mathrm{N}(2)-\mathrm{Zr}-\mathrm{O}(2)$ & $78.64(6)$ \\
$\mathrm{Zr}-\mathrm{Cl}(2)$ & $2.3967(8)$ & & \\
\hline
\end{tabular}


For all complexes $\mathbf{2 a - d}$, only a single set of signals is observed for the two enolatoimine-moieties which indicates a $C_{2}$-symmetric structure also in solution. For example, in $2 \mathrm{c}$, the $\mathrm{N}-\mathrm{C}=\mathrm{CH}$ proton resonance is observed as a singlet at $5.73 \mathrm{ppm}$ in comparison to $5.45 \mathrm{ppm}$ in the free ketoenamine. The characteristic NH-signal $(12.13 \mathrm{ppm})$ of the ketoenamine is absent. The singlet resonance of the $o-\mathrm{CH}_{3}$ protons is shifted downfield $v s$. the free ligand 1c $(1.72 \mathrm{ppm})$ to $2.22 \mathrm{ppm}$ in $2 \mathrm{c}$. Only one signal is observed for the aryl-bound $\mathrm{CH}_{3}$ groups and the $a$ - and $m$-carbon atoms, respectively in the ${ }^{13} \mathrm{C}$ NMR spectra. Analogously, only one set of signals is observed for the aryl moieties in $\mathbf{2 a}$ and $\mathbf{2 b}$. This is likely due to a rapid rotation of the aryl ring about the $\mathrm{N}-\mathrm{C}_{\text {aryl }}$ bond, since a rapid $\Delta-A$-isomerization which in case of a hindered $\mathrm{N}-\mathrm{C}_{\text {aryl }}$ bond rotation could alternatively explain the equivalency of all $o$ - and $m$-position has been reported to occur only at elevated temperatures in similat $C_{2}$-symmetric $\left(\mathrm{N}^{\wedge} \mathrm{O}\right)_{2} \mathrm{ZrX}_{2}$ complexes. ${ }^{13}$

In contrast to $\mathbf{2 a - c}$, the rotation of the aryl-substituents in $\mathbf{2 d}$ is clearly hindered on the NMR time-scale: Four methyl-dublets are observed for the isopropyl groups in the ' $\mathrm{H}$ NMR spectrum (0.78 ppm, $0.84 \mathrm{ppm}, 0.95 \mathrm{ppm}$ and $1.08 \mathrm{ppm}$, vs. $0.91 \mathrm{ppm}$ and $0.98 \mathrm{ppm}$ in the free ketoenamine) together with two septets for the methine-protons ( $2.73 \mathrm{ppm}$ and $2.86 \mathrm{ppm}$ vs. $2.77 \mathrm{ppm}$ ). Accordingly, two sets of signals for the $a$ - and $m$-carbon atoms are observed in the ${ }^{13} \mathrm{C}$ NMR spectrum.

While a more thorough analysis of a potential isomerization of complexes 2a-c by variable temperature NMR was not aim of this report, the spectroscopic observations obtained for $\mathbf{2 d}$ clearly indicate, that a rapid $\Delta-\Lambda$-isomerization (i.e. racemization) on the NMR time-scale (as well as any other isomerization) of $2 \mathrm{~d}$ at $25^{\circ} \mathrm{C}$ in solution can be excluded.

\section{Synthesis and characterization of dibenzyl complex $3 b$}

Slow addition of 2 equivalents of ketoenamine $1 \mathbf{b}$ to $\left[\mathrm{Zr}\left(\mathrm{CH}_{2} \mathrm{Ph}\right)_{4}\right]$ in toluene at $-30^{\circ} \mathrm{C}$ resulted in the formation of the dibenzyl complexes $\left[\left(\mathrm{N}^{\wedge} \mathrm{O}\right)_{2} \mathrm{Zr}\left(\mathrm{CH}_{2} \mathrm{Ph}\right)_{2}\right] \mathbf{3 b}$ (Scheme 2). Complex 3b was purified by recrystallization from pentane.

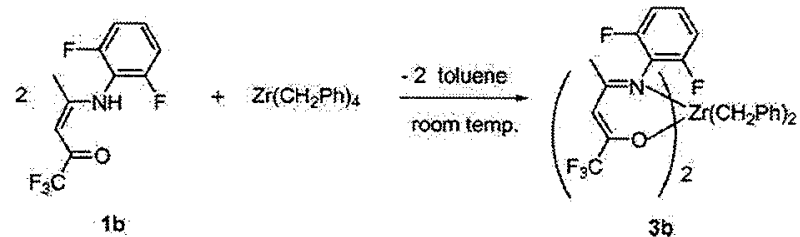

Scheme 2 Synthesis of complex $3 b$.

The room-temperature ${ }^{1} \mathrm{H}$ NMR spectrum of $\mathbf{3 b}$ features a single set of resonances for the ketoenamine ligand and the benzyl phenyl protons, and one sharp singlet for the $\mathrm{ZrCH}_{2}$ hydrogen atoms, which in contrast to the related dichloro complex $\mathbf{2 b}$ is indicative of a rapid $\Delta-\Lambda$-isomerization. Moreover, the benzyl complex $3 \mathrm{~b}$ does not show any of the NMR features typically associated with $\eta^{2}$-benzyl bonding. ${ }^{14}$ For example, the orthobenzyl protons do not appear upfield of $6.6 \mathrm{ppm}$ (3b: $6.80 \mathrm{ppm})$. Unfortunately, no crystals suited for X-ray structure analysis were obtained.

\section{Polymerization studies of ethylene}

Ethylene polymerizations were studied at 1 bar ethylene pressure and temperatures ranging from 0 to $50{ }^{\circ} \mathrm{C}$ (Table 2). Dichloro complexes $2 \mathrm{a}-\mathrm{d}$ were activated with 2000 equiv MAO (molar ratio) as a cocatalyst.

The substituents in the ortho position of the N-aryl moiety have a marked influence on the polymerization activity and the molecular weight of resulting polyethylenes. As a general trend, an increase in the steric bulk of $R$ results in reduced catalytic productivity. In detail, the activity of the $o$-fluorinated complex $\mathbf{2 b}$ is slightly higher than that of the non-fluorinated phenyl

Table 2 Ethylene polymerization results

\begin{tabular}{|c|c|c|c|c|c|c|c|c|c|c|}
\hline Entry & $\begin{array}{l}\text { catalyst } \\
\text { precursor }\end{array}$ & cat. $/ 10^{-6} \mathrm{~mol}$ & temp. $/{ }^{\circ} \mathrm{C}$ & time $/ \min$ & $\begin{array}{l}\operatorname{TOF}\left[\operatorname{mol}\left(\mathrm{C}_{2} \mathrm{H}_{4}\right)\right. \\
\left.\operatorname{mol}(\mathrm{Zr})^{-1} \mathrm{~h}^{-1}\right]\end{array}$ & $\begin{array}{l}\text { polymer } \\
\text { yield/g }\end{array}$ & $\begin{array}{l}M_{\mathrm{w}}^{6} / 10^{3} \mathrm{~g} \\
\mathrm{~mol}^{-1}\end{array}$ & $M_{\mathrm{w}} / M_{\mathrm{n}}{ }^{b}$ & Crystallinity $[\%]$ & $\mathrm{T}_{\mathrm{m}}{ }^{c} /{ }^{\circ} \mathrm{C}$ \\
\hline 1 & $2 \mathbf{a}$ & 1 & 25 & 5 & - & traces & 5.9 & 2.0 & - & - \\
\hline 2 & $2 a$ & 3 & 25 & 5 & 183000 & 1.28 & 8.1 & 2.9 & 77 & 126 \\
\hline 3 & $2 \mathbf{a}$ & 3 & 50 & 5 & 100000 & 0.70 & 4.7 & 2.4 & 88 & 126 \\
\hline 4 & $2 a$ & 5 & 25 & 5 & 180000 & 2.10 & 8.8 & 3.7 & 64 & 123 \\
\hline 5 & $2 \mathbf{b}$ & 1 & 25 & 5 & 129000 & 0.30 & 424 & 1.8 & 70 & 138 \\
\hline 6 & $2 \mathrm{~b}$ & 3 & 25 & 5 & 329000 & 2.30 & 384 & 2.0 & 57 & 137 \\
\hline 7 & $2 \mathrm{~b}$ & 3 & 50 & 5 & 283000 & 1.98 & 21 & 2.7 & 77 & 134 \\
\hline 8 & $2 \mathrm{~b}$ & 3 & 25 & 30 & 106000 & 4.45 & 217 & 2.5 & 69 & 139 \\
\hline 9 & $2 \mathrm{~b}$ & 3 & 0 & 5 & 203000 & 1.42 & 256 & 2.1 & 66 & 139 \\
\hline 10 & $2 \mathrm{c}$ & 5 & 25 & 30 & 710 & 0.05 & n.d..$^{d}$ & n.d. & 68 & 138 \\
\hline 11 & $2 \mathrm{c}$ & 5 & 50 & 30 & 1430 & 0.10 & 1021 & 2.8 & 69 & 138 \\
\hline 12 & $2 d$ & 5 & 25 & 30 & 570 & 0.04 & n.d. ${ }^{d}$ & n.d. & 77 & 138 \\
\hline 13 & $2 d$ & 5 & 50 & 30 & 290 & 0.02 & n.d..$^{d}$ & n.d. & 60 & 138 \\
\hline $14^{c}$ & $\mathbf{3 b}$ & 5 & 50 & 60 & 8570 & 1.20 & 860 & 5.6 & 63 & 140 \\
\hline $15^{f}$ & $\mathbf{3 b}$ & 5 & 50 & 120 & 360 & 0.10 & 430 & 3.5 & 75 & 138 \\
\hline $16^{8}$ & $3 \mathbf{b}$ & 5 & 50 & 120 & 1430 & 0.40 & n.d. ${ }^{d}$ & n.d. & 68 & 135 \\
\hline $17^{8}$ & $\mathbf{3 b}$ & 5 & 25 & 180 & 710 & 0.30 & 290 & 11.6 & 68 & 136 \\
\hline
\end{tabular}

${ }^{a}$ Reaction conditions: 1 bar ethylene, toluene $250 \mathrm{~mL}, 2000$ equiv MAO (molar ratio). ${ }^{b}$ Determined by GPC, referenced to linear PE ( $c f$. experimental part for details). ${ }^{c}$ Determined by DSC. ${ }^{\alpha}$ Analysis hampered by a strong pressure increase of the GPC columns, indicative of very high molecular weight fractions. 'Total amount of MAO applied: 1000 equiv and pre-activation of $3 \mathrm{~b}$ with 500 equiv MAO in the burette. ${ }^{f}$ Activation with 1 equiv $\left[\mathrm{Ph}_{3} \mathrm{C}\right]\left[\mathrm{B}\left(\mathrm{C}_{6} \mathrm{~F}_{5}\right)_{4}\right.$ in presence of 400 equiv TIBA. ${ }^{g}$ Activation with 1 equiv aniliniumborate in presence of 400 equiv TIBA. 
substituted analogue $2 \mathrm{a}$ under the same polymerization conditions (Table 2, entry 2 vs. entry 6). An analogous trend has been observed for other non-metallocene catalysts ${ }^{8,15,16}$ This observed behaviour can be attributed to the electron-withdrawing nature of the fluorinated ligand, which renders the metal center more electrophilic, and thus more reactive towards ethylene.

The dramatic reduction in polymerization productivity for bulky-substituted complexes $\mathbf{2 c , d}\left(\mathrm{R}=\mathrm{Me}\right.$, $\left.{ }^{\mathrm{i}} \mathrm{Pr}\right)$ indicates a hindrance of activation of the dichloro compounds, and possibly of chain growth by the $o$-substituents. An estimation of the number of active sites from the amount of polymer found and $M_{\mathrm{n}}$ indicates that for $2 \mathrm{c}$ less than $5 \%$ of the metal precursor is activated. High molecular weights of the polymers formed with $2 c$ and likely $2 d$ (GPC analysis was hampered by a strong pressure increase of the GPC columns, indicative of very high molecular weight fractions) indicate that chain transfer is retarded to a greater extent than chain growth by the $o$-substituents.

Well-behaved molecular weights distributions around $M_{\mathrm{w}} / M_{\mathrm{n}}$ -2 in various experiments point to a single site nature of the catalysts. Unlike the $\mathrm{Ti}$ analogue of $\mathbf{2 b}$, the zirconium complexes subject to this study do not polymerize ethylene in a living fashion. This parallels the behaviour of $\kappa^{2}-N, \mathrm{O}$ chelated salicylaldiminato complexes. ${ }^{7}$ Notably, $\mathrm{Zr}$ salicylaldiminato complexes bearing one or two isopropyl groups in ortho-position of the $\mathrm{N}$-aryl moiety resulted in significantly decreased activities and increased molecular weights as compared to a N-phenyl substituent. ${ }^{17}$

The lifetime of the most active catalyst, formed from $2 \mathbf{b}$, was investigated in a polymerization experiment over $30 \mathrm{~min}$ at $25^{\circ} \mathrm{C}$, monitored by a mass flow meter (Table 2, entry 8 and Fig. S1 in Supporting Information $\dagger$ ). Activity is stable over time, a slight decrease may be due to a minor decomposition of the catalytic active species, or to precipitation of the catalyst with the polymer formed.

Reaction of the benzyl complex $3 \mathrm{~b}$ with MAO, trityl borate (in the presence of triisobutyl (TIBA) aluminium scavenger) or anilinium borate provided an active catalyst less effectively than reaction of the dichloro compound (2b) with MAO, as evidenced by lower productivities and broader molecular weight distributions. Likewise, with $3 \mathrm{~b} / \mathrm{B}\left(\mathrm{C}_{6} \mathrm{~F}_{5}\right)_{3}$ in the presence of TIBA, no polymer was formed in these preliminary studies of activation.

\section{Polymerization of 1-olefins}

Propylene and 1-hexene polymerization were studied with catalyst precursor $\mathbf{2 b}$ which exhibited the highest activity in ethylene polymerization.

With $5 \mu \mathrm{mol}$ of $2 \mathrm{~b}, 1000$ equivalent $\mathrm{MAO}$ at $25^{\circ} \mathrm{C}$ and $2 \mathrm{bar}$ propylene pressure over a polymerization time of $2 \mathrm{~h}, 5.2 \mathrm{~g}$ of viscous, sticky and colourless low-molecular weight polypropylene were obtained $\left(M_{\mathrm{w}}=1.4 \times 10^{4} \mathrm{~g} \mathrm{~mol}^{-1}, M_{\mathrm{w}} / M_{\mathrm{n}}=2.1, T_{\mathrm{g}}=-13^{\circ} \mathrm{C}\right)$. This corresponds to an average activity of $12000 \mathrm{~mol}$ (propylene) $\operatorname{mol}(\mathrm{Zr})^{-1} \mathrm{~h}^{-1}$. High temperature ${ }^{13} \mathrm{C}$ NMR spectroscopy reveals the polymer to be atactic. The material is largely regioregular, with a small portion of observable regioirregular sequences ( $c f$. Supporting information, Figures $\mathrm{S} 4$ and $\mathrm{S5}$ ). ${ }^{1} \mathrm{H}$ and ${ }^{13} \mathrm{C}$ NMR spectroscopy (Fig. S2 and S3) reveal vinylidene endgroups. ${ }^{18}$

Exposure of $2 \mathrm{~b} / \mathrm{MAO}(5 \mu \mathrm{mol} / 500$ equiv) to neat 1 -hexene at ambient temperature for $10 \mathrm{~min}$ afforded $2 \mathrm{~g}$ of atactic poly(1- hexene), corresponding to an average activity of $28500 \mathrm{~mol}\left(\mathrm{C}_{6} \mathrm{H}_{12}\right)$ $\operatorname{mol}(\mathrm{Zr})^{-1} \mathrm{~h}^{-1}$. A molecular weight of $M_{\mathrm{w}}=4.7 \times 10^{3} \mathrm{~g} \mathrm{~mol}^{-1}$ and a molecular weight distribution $M_{\mathrm{w}} / M_{\mathrm{n}}$ of 2.3 were determined against polyethylene standards.

\section{Summary and conclusion}

A series of zirconium complexes $\left[\kappa^{2}-N, O-\left\{2,6-\mathrm{R}_{2} \mathrm{C}_{6} \mathrm{H}_{3} \mathrm{~N}=\mathrm{C}\right.\right.$ $\left(\mathrm{CH}_{3}\right) \mathrm{C}(\mathrm{H})=\mathrm{C}(\mathrm{O}) \mathrm{CF}_{3} \mathrm{l}_{2} \mathrm{ZrCl}_{2}$ of enolatoimines with an electronwithdrawing substituted alkoxy moiety, bearing different substituents in the 2,6-positions of the $\mathrm{N}$-aryl moiety were obtained by reaction of the corresponding ketoenamine with $\left[\mathrm{ZrCl}_{2}\left(\mathrm{CH}_{2} \mathrm{Ph}\right)_{2}\right]$. The steric bulk of the isopropyl analogue $\left(R={ }^{i} \mathrm{Pr}\right)$ is reflected both in the solution dynamics and solid state structure. Activation of the dichloro complexes with MAO affords active catalysts for the polymerization of ethylene to high molecular weight linear polyethylene and for the polymerization of propylene and 1-hexene to atactic polymer. Unlike the titanium analogue of $\mathbf{2 b}$, polymerization does not occur in a living fashion. Polymer molecular weight and catalyst productivities are strongly affected by the nature of the aryl substituents. An increasing steric bulk appears to retard activation of the precursors and/or chain growth, and even more pronouncedly chain transfer.

\section{Experimental section}

\section{Materials and general considerations}

All manipulations of air- and/or water-sensitive compounds were carried out under an inert atmosphere using standard glove box or Schlenk techniques. All glassware was flame-dried under vacuum before use. Toluene and benzene- $d_{6}$ were distilled from sodium under argon. Dichloromethane- $d_{2}$ was distilled from $\mathrm{CaH}_{2}$. THF$d_{8}$ was distilled from $\mathrm{Na} / \mathrm{K}$ alloy. 1,1,1-trifluoro-2,4-pentanedione were obtained from $\mathrm{ABCR} . \mathrm{ZrCl}_{4}$ and 2,6-diisopropylaniline ( $90 \%$ purity, technical) were received from Aldrich. $\left[\mathrm{Zr}\left(\mathrm{CH}_{2} \mathrm{Ph}\right)_{4}\right]$ and $\left[\mathrm{Cl}_{2} \mathrm{Zr}\left(\mathrm{CH}_{2} \mathrm{Ph}\right)_{2}{ }^{*} \mathrm{THF}\right]$ were supplied by MCAT (Konstanz, Germany). Ketoenamines (1a-c) were prepared according to published procedures. ${ }^{12}$ Methylalumoxane (MAO), purchased from Crompton as a $10 \mathrm{wt.} . \%$ solution in toluene, was evaporated to dryness at room temperature in vacuo, and stored as a solid white powder. 1-Hexene was purchased from Aldrich, stirred over molecular sieves for several days, degassed by three freeze-pump thaw cycles, vacuum distilled, and stored under nitrogen prior to use.

NMR spectra were recorded on a Varian Unity INOVA 400 spectrometer. ${ }^{1} \mathrm{H}$ and ${ }^{13} \mathrm{C}$ NMR chemical shifts were referenced to the solvent signal. The assignment of chemical shifts is based on ${ }^{1} \mathrm{H}-,{ }^{1} \mathrm{H},{ }^{1} \mathrm{H}$-gCOSY, $\left\{{ }^{1} \mathrm{H}\right\}{ }^{13} \mathrm{C}$-, DEPT $135,{ }^{1} \mathrm{H},{ }^{13} \mathrm{C}$ gHMQC, ${ }^{1} \mathrm{H},{ }^{13} \mathrm{C}$-gHMBC NMR experiments. High-temperature NMR spectroscopy of polypropylene was performed in 1,1,2,2tetrachlorethane- $d_{2}$ at $130^{\circ} \mathrm{C}$. A small amount of $\left[\mathrm{Cr}(\mathrm{acac})_{3}\right]$ was added as relaxation aid. ${ }^{13} \mathrm{C}$ NMR resonances of polypropylene were assigned according to ref. 19.

Differential scanning calorimetry (DSC) was performed on a Netzsch Phoenix $204 \mathrm{~F} 1$ at a heating/cooling rate of $10 \mathrm{~K} \mathrm{~min}^{-1}$. DSC data reported are from second heating cycles. Polymer crystallinities were calculated based on a melt enthalpy of $293 \mathrm{~J} \mathrm{~g}^{-1}$ for $100 \%$ crystalline polyethylene. Gel permeation chromatography 
(GPC) was carried out in 1,2,4-trichlorobenzene at $160^{\circ} \mathrm{C}$ at a flow rate of $1 \mathrm{~mL} \mathrm{~min}^{-1}$ on a Polymer Laboratories 220 instrument equipped with Olexis columns with differential refractive index, viscosity and light scattering $\left(15^{\circ}\right.$ and $\left.90^{\circ}\right)$ detectors. Data reported were determined via linear PE calibration $\left(M_{\mathrm{w}}<30000 \mathrm{~g}\right.$ mol $^{-1}$ ), universal calibration $\left(30000 \mathrm{~g} \mathrm{~mol}^{-1}<M_{\mathrm{w}}<100000 \mathrm{~g}\right.$ $\left.\mathrm{mol}^{-1}\right)$, and triple detection $\left(M_{\mathrm{w}}>100000 \mathrm{~g} \mathrm{~mol}^{-1}\right)$ employing the PL GPC-220 software algorithm. As the instrument records light scattering at only two angles, data analysis involves an iteration for the calculation of molecular weights and form factors for each measured interval. The instrument was calibrated with narrow polystyrene and polyethylene standards. Data given is referenced to linear polyethylene. Elemental analyses were performed up to $950^{\circ} \mathrm{C}$ on an Elementar Vario EL.

\section{Synthesis of the ketoenamine 1d}

To a stirred solution of 1,1,1-triffuoro-2,4-pentanedione $(3.0 \mathrm{~g}$, $2.36 \mathrm{ml}, 19.5 \mathrm{mmol}$ ) and p-toluenesulfonic acid (catalytic amount, around $5 \mathrm{mg}$ ) in dry toluene $(48 \mathrm{ml}$ ) was added 2,6diisopropylaniline $(23.4 \mathrm{mmol})$. The reaction mixture was refluxed at a temperature of $110^{\circ} \mathrm{C}$ over night on a soxhlet extractor filled with molecular sieve in order to remove water. The solution was concentrated in vacuum, and the crude product was purified by column chromatography (hexane- $\mathrm{Et}_{2} \mathrm{O}=7: 1$ ). Recrystallization of the resulting solid in ethanol afforded $1 \mathrm{~d}$ as white crystals (yield: $1.29 \mathrm{~g}, 4.1 \mathrm{mmol}, 21 \%)$.

4-(2,6-Diisopropylphenylamino)-1,1,1-trifluoro-pent-3-en-2-one (1d). ${ }^{1} \mathrm{H}$ NMR $\left(400 \mathrm{MHz}, \mathrm{C}_{6} \mathrm{D}_{6}, 25^{\circ} \mathrm{C}\right): \delta(\mathrm{ppm})=12.60(\mathrm{br}$, $1 \mathrm{H}, \mathrm{N} H), 7.10\left(\mathrm{t},{ }^{3} J_{\mathrm{HH}}=8 \mathrm{~Hz}, 1 \mathrm{H}\right.$, para $H$ to $\left.\mathrm{NH}\right), 6.95\left(\mathrm{~d},{ }^{3} J_{\mathrm{HH}}=\right.$ $8 \mathrm{~Hz}, 2 \mathrm{H}$, meta $H$ to $\mathrm{NH}), 5.53(\mathrm{~s}, 1 \mathrm{H}$, vinylic $H \mathrm{C}=\mathrm{C}), 2.77$ (sept, $\left.{ }^{3} J_{\mathrm{HH}}=8 \mathrm{~Hz}, 2 \mathrm{H}, \mathrm{iPr} \mathrm{CH}\right), 1.24\left(\mathrm{~s}, 3 \mathrm{H}, \mathrm{CH}_{3}\right), 0.98\left(\mathrm{~d},{ }^{3} J_{\mathrm{HH}}=\right.$ $\left.7 \mathrm{~Hz}, 6 \mathrm{H}, \mathrm{iPrCH}{ }_{3}\right), 0.91\left(\mathrm{~d},{ }^{3} J_{\mathrm{HH}}=8 \mathrm{~Hz}, 6 \mathrm{H}, \mathrm{iPrCH}{ }_{3}\right) .{ }^{13} \mathrm{CNMR}$ $\left(100 \mathrm{MHz}, \mathrm{C}_{6} \mathrm{D}_{6}, 25^{\circ} \mathrm{C}\right): \delta(\mathrm{ppm})=177.23\left(\mathrm{q},{ }^{2} J_{\mathrm{CF}}=32.7 \mathrm{~Hz}\right.$, $\mathrm{CF}_{3} \mathrm{CO}$ ), 170.36 (vinylic $C$ ), 145.67 (ortho $C$ ), 132.36 (ipso $C$ ), 129.41 (para C), 124.10 (meta C), $118.56\left(\mathrm{q},{ }^{1} J_{\mathrm{CF}}=288.2 \mathrm{~Hz}\right.$, $\mathrm{CF}_{3}$ ), 89.76 (q, ${ }^{4} J_{\mathrm{CF}}=1.2 \mathrm{~Hz}$, vinylic $\mathrm{CH}$ ), 28.86 (iPr $\mathrm{CH}$ ), 24.19 (iPr $\left.\mathrm{CH}_{3}\right), 22.39\left(\mathrm{iPr} \mathrm{CH}_{3}\right), 18.97\left(\mathrm{CH}_{3}\right) .{ }^{19} \mathrm{~F} \mathrm{NMR}(375 \mathrm{MHz}$, $\left.\mathrm{C}_{6} \mathrm{D}_{6}, 25^{\circ} \mathrm{C}\right): \delta(\mathrm{ppm})=-76.53\left(\mathrm{~s}, \mathrm{C} F_{3} \mathrm{CO}\right)$. Anal. calcd. $(\%)$ for $\mathrm{C}_{17} \mathrm{H}_{22} \mathrm{~F}_{3} \mathrm{NO}: \mathrm{C}, 65.16 ; \mathrm{H}, 7.08 ; \mathrm{N}, 4.47$; Found: C, 65.17; H, 7.17; $\mathrm{N}, 4.53$. MS (m/z, \%): $314.3\left(100.0,[\mathrm{M}+\mathrm{H}]^{+}\right)$.

\section{Synthesis of dichloro complexes $2 a-d$}

A solution of ketoenamine $(0.1 \mathrm{mmol})$ in toluene was added dropwise to a toluenic solution of $\left[\mathrm{Cl}_{2} \mathrm{Zr}\left(\mathrm{CH}_{2} \mathrm{Ph}\right)_{2}{ }^{*} \mathrm{THF}\right](0.05 \mathrm{mmol})$ at $-30^{\circ} \mathrm{C}$. A colour change was observed immediately. By evaporation of the solvent in vacuo, analytically pure material was obtained.

Dichloro-bis $\left[\kappa^{2}-N, O-4\right.$-phenylimino-1,1,1-triftuoropent-2-en-2olatolzirconium(IV) (2a). ${ }^{\prime} \mathrm{H} \mathrm{NMR}\left(400 \mathrm{MHz}, \mathrm{THF}-d_{8}, 25^{\circ} \mathrm{C}\right)$ : $\delta(\mathrm{ppm})=7.39\left(\mathrm{t},{ }^{3} J_{\mathrm{HH}}=7.8 \mathrm{~Hz}, 1 \mathrm{H}\right.$, para $\left.H\right), 7.27-7.22(\mathrm{~m}, 2 \mathrm{H}$, meta $H), 6.99\left(\mathrm{~d},{ }^{3} J_{\mathrm{HH}}=7.2 \mathrm{~Hz}, 2 \mathrm{H}\right.$, ortho $\left.\mathrm{H}\right), 5.88(\mathrm{~s}, 1 \mathrm{H}$, vinylic $\mathrm{CH}), 1.93\left(\mathrm{~s}, 3 \mathrm{H}, \mathrm{CH}_{3}\right) .{ }^{13} \mathrm{C}$ NMR $\left(100 \mathrm{MHz}, \mathrm{THF}-d_{8}, 25^{\circ} \mathrm{C}\right)$ $\delta(\mathrm{ppm})=177.43($ imine $C), 155.66\left(\mathrm{q},{ }^{2} J_{\mathrm{CF}}=35 \mathrm{~Hz}, \mathrm{CF}_{3} C \mathrm{O}\right)$, 147.28 (ipso C), 130.24 (para C), 127.59 (meta C), 124.38 (ortho C), $119.58\left(\mathrm{q}, J_{\mathrm{CF}}=279 \mathrm{~Hz}, C F_{3}\right.$ ), 105.14 (vinylic $C$ ), 24.48 $\left(\mathrm{CH}_{3}\right) .{ }^{19} \mathrm{~F}$ NMR $\left(376 \mathrm{MHz}, \mathrm{THF}-d_{8}, 25^{\circ} \mathrm{C}\right): \delta(\mathrm{ppm})=-72.64$ (s, $\mathrm{C} F_{3} \mathrm{CO}$ ). Anal. calcd. (\%) for $\mathrm{C}_{22} \mathrm{H}_{18} \mathrm{Cl}_{2} \mathrm{~F}_{6} \mathrm{~N}_{2} \mathrm{O}_{2} \mathrm{Zr}$ : C, 42.72; $\mathrm{H}$, $2.93 ; \mathrm{N}, 4.53$; Found: $\mathrm{C}, 42.62 ; \mathrm{H}, 3.03 ; \mathrm{N}, 4.54$.

Dichloro-bis[ $\kappa^{2}-N, O-4-(2,6$-difluorophenylimino)-1,1,1-trifluoropent-2-en-2-olatolzirconium(IV) (2b). ${ }^{1} \mathrm{H}$ NMR $(400 \mathrm{MHz}$, $\left.\mathrm{CD}_{2} \mathrm{Cl}_{2}, 25^{\circ} \mathrm{C}\right): \delta(\mathrm{ppm})=7.36-7.27(\mathrm{~m}, 1 \mathrm{H}$, para $H), 7.05-6.97$ $(\mathrm{m}, 2 \mathrm{H}$, meta $\mathrm{H}), 6.03(\mathrm{~s}, 1 \mathrm{H}$, vinylic $\mathrm{CH}), 2.01\left(\mathrm{~s}, 3 \mathrm{H}, \mathrm{CH}_{3}\right) \cdot{ }^{13} \mathrm{C}$ NMR (100 MHz, $\left.\mathrm{CD}_{2} \mathrm{Cl}_{2}, 25^{\circ} \mathrm{C}\right): \delta(\mathrm{ppm})=180.93$ (imine $C$ ), $156.87\left(\mathrm{q},{ }^{2} J_{\mathrm{CF}}=36 \mathrm{~Hz}, \mathrm{CF}_{3} \mathrm{CO}\right), 155.56\left(\mathrm{~d},{ }^{1} J_{\mathrm{CF}}=253 \mathrm{~Hz}\right.$, ortho C), 129.19 (para C), 123.66 (ipso C), 118.82 (q, ${ }^{1} J_{\mathrm{CF}}=$ $\left.277 \mathrm{~Hz}, C_{3}\right), 112.85\left(\mathrm{t},{ }^{2} J_{\mathrm{CF}}=19 \mathrm{~Hz}\right.$, meta $C$ ), 105.23 (vinylic C), $25.42\left(\mathrm{CH}_{3}\right) \cdot{ }^{19} \mathrm{~F} \mathrm{NMR}\left(376 \mathrm{MHz}, \mathrm{CD}_{2} \mathrm{Cl}_{2}, 25^{\circ} \mathrm{C}\right): \delta(\mathrm{ppm})=$ -74.24 (s, 3F, $\mathrm{CF}_{3} \mathrm{CO}$ ), -118.09 (s, 2F, aryl $F$ ). Anal. calcd. (\%) for $\mathrm{C}_{22} \mathrm{H}_{14} \mathrm{Cl}_{2} \mathrm{~F}_{10} \mathrm{~N}_{2} \mathrm{O}_{2} \mathrm{Zr}$ : C, 38.27; H, 2.04; N, 4.06; Found: C, 38.37; $\mathrm{H}, 2.07 ; \mathrm{N}, 4.07$.

Dichloro-bis $\left[\kappa^{2}-N, O-4-(2,6\right.$-dimethylphenylimino)-1,1,1-trifluoropent-2-en-2-olatolzirconium(IV) (2c). ' $\mathrm{H}$ NMR (400 $\mathrm{MHz}$, $\left.\mathrm{C}_{6} \mathrm{D}_{6}, 25^{\circ} \mathrm{C}\right): \delta(\mathrm{ppm})=6.92-6.89(\mathrm{br}, 3 \mathrm{H}$, aryl $H), 5.73(\mathrm{~s}, 1 \mathrm{H}$, vinylic $\mathrm{CH}), 2.22\left(\mathrm{~s}, 6 \mathrm{H}\right.$, aryl $\left.\mathrm{CH}_{3}\right), 1.97\left(\mathrm{~s}, 3 \mathrm{H}, \mathrm{CH}_{3}\right) .{ }^{13} \mathrm{C}$ NMR $\left(100 \mathrm{MHz}, \mathrm{C}_{6} \mathrm{D}_{6}, 25^{\circ} \mathrm{C}\right): \delta(\mathrm{ppm})=177.87($ imine $C), 157.79(\mathrm{q}$, ${ }^{2} J_{\mathrm{CF}}=35 \mathrm{~Hz}, \mathrm{CF}_{3} \mathrm{CO}$ ), 146.39 (ipso C), 131.47 (ortho C), 129.72 (para C), 127.78 (meta C), $120.00\left(\mathrm{q},{ }^{1} J_{\mathrm{CF}}=278 \mathrm{~Hz}, C_{3}\right.$ ), 105.04 (q, ${ }^{3} J_{\mathrm{CF}}=3.1 \mathrm{~Hz}$, vinylic $\mathrm{C}$ ), $23.59\left(\mathrm{CH}_{3}\right), 19.10\left(\operatorname{aryl~} \mathrm{CH}_{3}\right) .{ }^{19} \mathrm{~F}$ NMR (376 MHz, $\left.\mathrm{C}_{6} \mathrm{D}_{6}, 25^{\circ} \mathrm{C}\right): \delta(\mathrm{ppm})=-73.74\left(\mathrm{~s}, \mathrm{CF}_{3} \mathrm{CO}\right)$. Anal. calcd. (\%) for $\mathrm{C}_{26} \mathrm{H}_{26} \mathrm{Cl}_{2} \mathrm{~F}_{6} \mathrm{~N}_{2} \mathrm{O}_{2} \mathrm{Zr}$ : C, 46.29; $\mathrm{H}, 3.88 ; \mathrm{N}$, 4.15; Found: C, 46.37; H, 3.99; N, 4.10 .

Dichloro-bis $\left[\kappa^{2}-N, O-4\right.$-(2,6-diisopropylhenylimino)-1,1,1-trifluoropent-2-en-2-olatolzirconium(IV) (2d). ' $\mathrm{H} \mathrm{NMR}(400 \mathrm{MHz}$, $\left.\mathrm{CD}_{2} \mathrm{Cl}_{2}, 25^{\circ} \mathrm{C}\right): \delta(\mathrm{ppm})=7.06-6.99(\mathrm{~m}, 1 \mathrm{H}$, para $H), 6.99-6.95$ $\left(\mathrm{d},{ }^{3} J_{\mathrm{HH}}=6.4 \mathrm{~Hz}, 1 \mathrm{H}\right.$, meta $\left.\mathrm{H}\right), 6.95-6.90\left(\mathrm{~d},{ }^{3} J_{\mathrm{HH}}=7.6,1 \mathrm{H}\right.$, meta $H), 5.84(\mathrm{~s}, 1 \mathrm{H}$, vinylic $\mathrm{CH}), 2.86\left(\mathrm{sept},{ }^{3} \mathrm{~J}_{\mathrm{HH}}=6.6 \mathrm{~Hz}, 1 \mathrm{H}, \mathrm{PPr}\right.$ $\mathrm{CH}), 2.73$ (sept, $\left.{ }^{3} J_{\mathrm{HH}}=6.8 \mathrm{~Hz}, 1 \mathrm{H}, \mathrm{iPr} \mathrm{CH}\right), 1.69\left(\mathrm{~s}, 3 \mathrm{H}, \mathrm{CH}_{3}\right)$, $1.08\left(\mathrm{~d},{ }^{3} J_{\mathrm{HH}}=6.4 \mathrm{~Hz}, 3 \mathrm{H}, \mathrm{iPr} \mathrm{CH} H_{3}\right), 0.95\left(\mathrm{~d},{ }^{3} J_{\mathrm{HH}}=6.4 \mathrm{~Hz}, 3 \mathrm{H}\right.$, iPr $\left.\mathrm{CH}_{3}\right), 0.84\left(\mathrm{~d},{ }^{3} J_{\mathrm{HH}}=6.8 \mathrm{~Hz}, 1 \mathrm{H}, \mathrm{iPr} \mathrm{CH} \mathrm{CH}_{3}\right), 0.78\left(\mathrm{~d},{ }^{3} J_{\mathrm{HH}}=\right.$ $6.8 \mathrm{~Hz}, 1 \mathrm{H}$, iPr $\left.\mathrm{CH}_{3}\right) .{ }^{13} \mathrm{C}$ NMR $\left(100 \mathrm{MHz}, \mathrm{CD}_{2} \mathrm{Cl}_{2}, 25^{\circ} \mathrm{C}\right): \delta$ $(\mathrm{ppm})=177.89($ imine $C), 156.16\left(\mathrm{q},{ }^{2} J_{\mathrm{CF}}=35.3 \mathrm{~Hz}, \mathrm{CF}_{3} \mathrm{CO}\right)$, 146.18 (ipso C), 142.10 (ortho $C$ ), 140.96 (ortho $C$ ), 128.13 (para C), 125.26 (meta C), 124.70 (meta C), 119.30 (q, ' $J_{C F}=277.7 \mathrm{~Hz}$, $\mathrm{CF}_{3}$ ), 103.73 (vinylic $\mathrm{C}$ ), $26.65\left(\mathrm{CH}_{3}\right), 28.45$ (iPr $\mathrm{CH}$ ), 28.37 (iPr $\mathrm{CH}), 25.33\left(\mathrm{iPr} \mathrm{CH}_{3}\right), 24.98\left(\mathrm{iPr} \mathrm{CH}_{3}\right), 24.80\left(\mathrm{iPr} \mathrm{CH}_{3}\right), 24.07(\mathrm{iPr}$ $\left.\mathrm{CH}_{3}\right) .{ }^{19} \mathrm{~F}$ NMR $\left(376 \mathrm{MHz}, \mathrm{CD}_{2} \mathrm{Cl}_{2}, 25^{\circ} \mathrm{C}\right): \delta(\mathrm{ppm})=-74.58(\mathrm{~s}$, $3 \mathrm{~F}, \mathrm{C} F_{3} \mathrm{CO}$ ). Anal. calcd. (\%) for $\mathrm{C}_{34} \mathrm{H}_{42} \mathrm{Cl}_{2} \mathrm{~F}_{6} \mathrm{~N}_{2} \mathrm{O}_{2} \mathrm{Zr}$ : C, 51.90; $\mathrm{H}, 5.38$; N, 3.56; Found: C, 52.03; H, 5.40; N, 3.58.

\section{Synthesis of dibenzyl complexes}

A solution of $1 \mathrm{~b}(13.3 \mathrm{mg}, 0.05 \mathrm{mmol})$ in toluene $(5 \mathrm{~mL})$ was added dropwise at $-30{ }^{\circ} \mathrm{C}$ to a solution of $\left[\mathrm{Zr}\left(\mathrm{CH}_{2} \mathrm{C}_{6} \mathrm{H}_{5}\right)_{4}\right](11.4 \mathrm{mg}$, $0.025 \mathrm{mmol})$ in toluene $(5 \mathrm{~mL})$. The yellow solution turned to orange-reddish and was stirred for $1 \mathrm{~h}$. The volatiles were removed under vacuum. The crude product was recrystallized from pentane at $-30^{\circ} \mathrm{C}$.

Dibenzyl-bis[ $\left[\kappa^{2}-N, O-4-(2,6\right.$-difluorophenylimino)-1,1,1-trifluoropent-2-en-2-olato]zirconium(IV) (3b). ' $\mathrm{H}$ NMR $(400 \mathrm{MHz}$, Tol- $\left.d_{8}, 25^{\circ} \mathrm{C}\right): \delta(\mathrm{ppm})=7.06\left(\mathrm{vt},{ }^{3} J_{\mathrm{HH}}=7.0 \mathrm{~Hz}, 2 \mathrm{H}\right.$, meta $\mathrm{CH}$ of benzyl), $6.88\left(\mathrm{t},{ }^{3} J_{\mathrm{HH}}=7.2 \mathrm{~Hz}, 1 \mathrm{H}\right.$, para $\mathrm{CH}$ of benzyl), $6.80\left(\mathrm{~d},{ }^{3} J_{\mathrm{HH}}=7.6 \mathrm{~Hz}, 2 \mathrm{H}\right.$, ortho $\mathrm{CH}$ of benzyl), $6.40(\mathrm{~m}, 3 \mathrm{H}$, aryl), $5.18(\mathrm{~s}, 1 \mathrm{H}$, vinylic $\mathrm{CH}=\mathrm{C}), 2.12\left(\mathrm{~s}, 2 \mathrm{H}, \mathrm{CH}_{2}\right), 1.45(\mathrm{~s}, 3 \mathrm{H}$, 
$\left.\mathrm{C} H_{3}\right) \cdot{ }^{13} \mathrm{CNMR}\left(101 \mathrm{MHz}\right.$, Tol- $\left.d_{8}, 25^{\circ} \mathrm{C}\right): \delta(\mathrm{ppm})=176.8$ (imine C), $155.7\left(\mathrm{~d},{ }^{1} J_{\mathrm{CF}}=251.8 \mathrm{~Hz}\right.$, ortho $\left.C\right), 155.6\left(\mathrm{q},{ }^{2} J_{\mathrm{CF}}=34.3 \mathrm{~Hz}\right.$, $\mathrm{CF}_{3} \mathrm{CO}$ ), 154.4 (br, ipso C), 143.5 (ipso $C$ of benzyl), 129.5 (ortho $C$ of benzyl), 129.3 (meta $C$ of benzyl), 127.2 (m, para $C$ ), 123.3 (para $C$ of benzyl), $119.8\left(\mathrm{q},{ }^{1} J_{\mathrm{CF}}=279.6 \mathrm{~Hz}, C \mathrm{~F}_{3}\right), 112.2(\mathrm{br}$, meta C), 103.2 (vinylic $C=\mathrm{CH}), 68.0\left(\mathrm{CH}_{2}\right.$ of benzyl), $24.8\left(\mathrm{CH}_{3}\right) .{ }^{19} \mathrm{~F}$ NMR (376 MHz, Tol- $\left.d_{8}, 25^{\circ} \mathrm{C}\right): \delta(\mathrm{ppm})=-73.73\left(\mathrm{~s}, 3 \mathrm{~F}, \mathrm{C} F_{3} \mathrm{CO}\right)$, $-114.27(\mathrm{~s}, 1 \mathrm{~F}$, aryl $\mathrm{F})$ and $-116.93(\mathrm{~s}, 1 \mathrm{~F}$, aryl F).

\section{Ethylene or propylene polymerization}

Ethylene and propylene, respectively, polymerization was carried out under atmospheric pressure in a thermostated $500 \mathrm{~mL}$ doublemantle glass reactor equipped with a mechanical stirrer. Toluene $(200 \mathrm{~mL})$ was introduced into the nitrogen-purged reactor and stirred vigorously $(500 \mathrm{rpm})$. The toluene was kept at the desired polymerization temperature, and then the ethylene gas feed was started. After $15 \mathrm{~min}$, polymerization was initiated by the addition of a toluene solution of MAO followed by a toluene solution of the respective $\mathrm{Zr}$ complex into the reactor, such that the total volume of toluene in the reactor was $250 \mathrm{~mL}$. After the desired reaction time, ethanol $(5 \mathrm{~mL})$ was added to terminate the polymerization reaction, and the ethylene gas feed was stopped. The reaction mixture was added to acidified methanol $(1 \mathrm{~mL}$ of concentrated $\mathrm{HCl}$ in $500 \mathrm{~mL}$ of methanol). Solid polyethylene was recovered by filtration, washed with methanol, and dried at $50^{\circ} \mathrm{C}$ for $24 \mathrm{~h}$ in a vacuum oven.

\section{1-Hexene polymerization}

In the glove box, $500 \mathrm{eq}$. MAO (145 mg) was added to $5 \mathrm{~g} 1$-hexene in a Schlenk flask. To this solution was added a dichloromethane solution of $5 \mu \mathrm{mol}$ of the catalyst precursor $2 \mathrm{~b}(3.4 \mathrm{mg})$, and the reaction was allowed to proceed with continuous stirring for the desired period of time. The polymerization was quenched with $5 \mathrm{~mL}$ of acidified $(\mathrm{HCl})$ methanol. The polymer was extracted with hexane and dried under vacuum.

\section{X-ray crystal structure determinations}

The data collection was performed at $100 \mathrm{~K}$ on a STOE IPDS-II diffractometer equipped with a graphite-monochromated radiation source $(\lambda=0.71073 \AA)$ and an image plate detection system. A crystal mounted on a fine glass fibre with silicon grease was employed. The selection, integration and averaging procedure of the measured reflex intensities, the determination of the unit cell dimensions by a least-squares fit of the $2 \Theta$ values, data reduction, LP-correction and space group determination were performed using the X-Area software package of the diffractometer. A semiempirical absorption correction was performed. The structure was solved by direct methods (SHELXS-97), completed with difference Fourier syntheses, and refined with full-matrix leastsquares using SHELXL-97 minimizing $w\left(\mathrm{Fo}^{2}-\mathrm{Fc}^{2}\right)^{2}$. Weighted $R$ factor (wR) and the goodness of fit $S$ are based on $F^{2}$; the conventional $R$ factor $(R)$ is based on $F$. All non-hydrogen atoms were refined with anisotropic displacement parameters. All scattering factors and anomalous dispersion factors are provided by the SHELXL-97 program.

\section{Acknowledgements}

Financial support by the DFG (Me 1388/3-3) is gratefully acknowledged. S. M. is indebted to the Fonds der Chemischen Industrie. We thank Lars Bolk (Konstanz) for GPC analysis.

\section{Notes and references}

$1(a)$ H. H. Brintzinger, D. Fischer, R. Mülhaupt, B. Rieger and R. M. Waymouth, Angew. Chem., Int. Ed. Engl., 1995, 34, 1143; (b) R. Mülhaupt, Macromol. Chem. Phys., 2003, 204, 289.

2 (a) G. W. Coates, P. D. Hustad and S. Reinartz, Angew. Chem. Int. Ed. 2002, 41, 2236; (b) H. Makio, N. Kashiwa and T. Fujita, Adv. Synth Catal., 2002, 344, 477; (c) G. J. Domski, J. M. Rose, G. W. Coates, A. D. Bolig and M. Brookhart, Prog. Polym. Sci., 2007, 32, 30; (d) H. Makio and T. Fujita, Acc. Chem. Res., 2009, 42, 1532.

3 (a) G. J. P. Britovsek, V. C. Gibson and D. F. Wass, Angew. Chem., Int. Ed., 1999, 38, 428; (b) S. D. Ittel, L. K. Johnson and M. Brookhart, Chem. Rev., 2000, 100, 1169; (c) S. Mecking, Angew. Chem., Int. Ed., $2001,40,534 ;(d)$ V. C. Gibson and S. K. Spitzmesser, Chem. Rev. 2003, 103, 283; (e) A. Berkefeld and S. Mecking, Angew. Chem., Int. Ed., $2008,47,2538$.

4 (a) J. Saito, M. Mitani, J. Mohri, Y. Yoshida, S. Matsui, S. Ishii, S. Kojoh, N. Kashiwa and T. Fujita, Angew. Chem., Int. Ed, 2001, 40, 2918; (b) M. Mitani, J. Mohri, Y. Yoshida, J. Saito, S. Ishii, K. Tsuru, S. Matsui, R. Furuyama, T. Nakano, H. Tanaka, S. Kojoh, T. Matsugi, N. Kashiwa and T. Fujita, J. Am. Chem. Soc., 2002, 124, 3327.

5 S. Reinartz, A. F. Mason, E. B. Lobkovsky and G. W. Coates, Organometallics, 2003, 22, 2542 .

6 (a) J. Saito, M. Mitani, M. Onda, J. Mohri, S. Ishii, Y. Yoshida, T. Nakano, H. Tanaka, S. Matsugi, T. Kojoh, N. Kashiwa and T. Fujita, Macromol. Rapid Commun., 2001, 22, 1072; (b) M. Mitani, R. Furuyama, J. Mohri, J. Saito, S. Ishii, H. Terao, T. Nakano, H. Tanaka and T. Fujita, J. Am. Chem. Soc, 2003, 125, 4293.

7 (a) S. Matsui, M. Mitani, J. Saito, Y. Tohi, H. Makio, H. Tanaka and T. Fujita, Chem. Lett., 1999, 1263; (b) S. Matsui, M. Mitani, J. Saito, N. Matsukawa, H. Tanaka, T. Nakano and T. Fujita, Chem. Lett., 2000, 554.

8 S. Chen, X. Zhang, H. Ma, Y. Lu, Z. Zhang, H. Li, N. Cui and Y. Hu, J. Organomet. Chem., $2005,690,4184$.

9 (a) 1. Göttker-Schnetmann, B. Korthals and S. Mecking, J. Am. Chem. Soc., 2006, 128, 7708-7709; (b) C. H. M. Weber, A. Chiche, G. Krausch, S. Rosenfeldt, M. Ballauff, L. Harnau, I. Göttker-Schnetmann, Q. Tong and S. Mecking, Nano Lett., 2007, 7, 2024.

$10(a)$ D. Jones, A. Roberts, K. Cavell, W. Keim, U. Englert, B. W. Skelton and A. H. White, J. Chem. Soc, Dalton Trans, 1998, 255; (b) D. Jones, K. Cavell and W. Keim, J. Mol. Catal. A: Chem., 1999, 138, 37; (c) J. Kim, J.W. Hwang, Y. Kim, M. H. Lee, Y. Han and Y. Do, J. Organomet. Chem., 2001, 620, 1; (d) X.-F. Li, K. Dai, W.-P. Ye, L. Pan and Y.-S. Li, Organometallics, 2004, 23, 1223; (e) L.-M. Tang, T. Hu, Y.-J. Bo, Y.-S. $\mathrm{Li}$ and N.-H. Hu, J. Organomet. Chem., 2005, 690, 3125; (f) W.-P. Ye, J Zhan, L. Pan, N.-H. Hu and Y.-S. Li, Organometallics, 2008, 27, 3642; (g) P. Li, M. Hong, J.-Y. Liu, W.-P. Ye and Y.-S. Li, Macromolecules, 2009, 42, 4391; $(h)$ N. Marquet, E. Kirillov, T. Roisnel, A. Razavi and J.-F. Carpentier, Organometallics, 2009, 28,606; (i) A.-Q. Jia and G.-X. Jin, Dalton Trans., 2009, 8838; (j) Y.-B. Huang and G.-X. Jin, Dalton Trans., 2009, 767.

$11(a)$ L. Zhang, M. Brookhart and P. S. White, Organometallics, 2006,25 1868; (b) S.-M. Yu, A. Berkefeld, I. Göttker-Schnetmann, G. Müller and S. Mecking, Macromolecules, 2007, 40, 421; (c) S.-M. Yu and S. Mecking, Macromolecules, 2009, 42, 3669.

12 S.-M. Yu and S. Mecking, J. Am. Chem. Soc., 2008, 130, 13204.

13 E.g.: (a) X. Bei, D. C. Swenson and R. F. Jordan, Organometallics, 1997, 16, 3282; (b) L. Lavanant, T.-Y. Chou, Y. Chi, C. W. Lehmann, L. Toupet and J.-F. Carpentier, Organometallics, 2004, 23, 5450; (c) J. Niemeyer, G. Kehr, R. Fröhlich and G. Erker, Dalton Trans., 2009, 3731 .

14 (a) S. L. Latesky, A. K. McMullen, G. P. Niccolai, I. P. Rothwell and J. C. Huffman, Organometallics, 1985, 4, 902; (b) M. Bochmann and S. J. Lancaster, Organometallics, 1993, 12, 633; (c) M. Bochmann, S. J Lancaster, M. B. Hursthouse and K. M. A. Malik, Organometallics, 
1994, 13, 2235; (d) R. F. Jordan, R. E. LaPointe, C. S. Bajgur, S. F. Echolls and R. Willet, J. Am. Chem. Soc., 1987, 109, 4111; (e) R. F. Jordan, R. E. LaPointe, N. Baenziger and G. D. Hinch, Organometallics, $1990,9,1539$.

15 (a) S. Ishii, J. Saito, M. Mitani, J. Mohri, N. Matsukawa, N. Kashiwa and T. Fujita, J. Mol. Catal. A: Chem., 2002, 179, 11 (b) S.-I. Ishii, R. Furuyama, N. Matsukawa, J. Saito, M. Mitani, H. Tanaka and T. Fujita, Macromol. Rapid Commun., 2003, 24, 452.

$16(a)$ E. A. C. Brussee, A. Meetsma, B. Hessen and J. H. Teuben, Chem Commun., 2000, 497; (b) T. Matsugi, S. Matsui, S. Kojoh, Y. Takagi, Y.
Inoue, T. Nakano, T. Fujita and N. Kashiwa, Macromolecules, 2002, 35,4880 .

17 S. Matsui, M. Mitani, J. Saito, Y. Tohi, H. Makio, N. Matsukawa, Y. Takagi, K. Tsuru, M. Nitaburu, H. Tanaka, N. Kashiwa and T. Fujita, J. Am. Chem. Soc, $2001,123,6847$.

18 Vinylidene end groups: $=\mathrm{CH}^{\prime} H^{2}$ at $\delta=4.76$ and $4.83 \mathrm{ppm}, \mathrm{CH}_{3}$ resonance at $\delta=1.8 \mathrm{ppm}$. While the $\mathrm{CH}_{2}$ resonance is observed at $111.6 \mathrm{ppm}$, the quaternary carbon atom $\left(C^{2}\right)$ resonance expected at $\delta=144.6 \mathrm{pm}$ was not observable despite addition of $\left[\mathrm{Cr}(\mathrm{acac})_{3}\right]$ as relaxation aid.

19 H. N. Cheng, Polymer Bulletin, 1985, 14, 347. 
